\title{
EFFICIENCY OF THE DYNAMIC GEOMETRY SOFTWARE FOR SELF- EDUCATION ON ONE GEOMETRIC CONCEPT
}

\author{
NOCAR David - ZDRÁHAL Tomáš, CZ
}

\begin{abstract}
The paper deals with the research project concerning the efficiency of GeoGebra for self-education on the geometric concept regular tessellations to compare with the traditional methods (paper and pencil or using paper models). The project was provided on the sample of more than 70 students of non-mathematics bachelor studies. Our results point that GeoGebra (i.e. Dynamic Geometry Software) does not have to be all the time better than traditional methods, especially if it is used exclusively for self-education.
\end{abstract}

Keywords: regular polygons, regular tessellations, dynamic geometry software

\section{EFEKTIVITA SOFTWARU DYNAMICKÉ GEOMETRIE PŘI SAMOSTUDIU NA PŘÍKLADĚ JEDNOHO GEOMETRICKÉHO KONCEPTU}

\section{Resumé}

Článek prezentuje výzkumný projekt týkající se efektivity využití programu GeoGebra při samostudiu realizovaného na základě geometrického principu pravidelných teselací v porovnání s tradičními metodami (tužkou na papír či použitím papírových modelů). Projekt byl realizován na vzorku více než 70 studentů nematematických bakalářských studijních oborů. Naše výsledky ukazují, že použití programu GeoGebra (prríklad softwaru dynamické geometrie) nemusí být vždy lepší než tradiční metody, zejména pokud se používá výlučně pro samostudium.

Klíčová slova: pravidelné mnohoúhelníky, pravidelné teselace, software dynamické geometrie

\section{Dynamic Geometry Software}

According to the even relatively old bibliography (e.g. Clements and Battista, 1992), the results show that Dynamic Geometry Software is rather efficient in the learning of geometry. The learning of geometrical concepts would be made easier by the fact that the constructions take place in a direct way; users' actions are based upon formal geometrical aspects. There is a question here, however: Is Dynamic Geometry Software panacea, i.e. is Dynamic Geometry Software something that will solve all problems (in Geometry)?

However, the actual trend in education known as Inquiry-based education offers especially in geometry space for inquiry and discovery. The situation is enhanced by the potential of dynamic geometry software that are especially suitable for inquiry and experimentation. (e.g. Nocar - Novák, 2015; Nocar - Zdráhal, 2015).

\section{Problems concerning Regular Tessellations}

We made the research concerning the relation among the use of traditional method (students' work with textbooks), enhanced traditional methods (using of so called Material Cards) and GeoGebra Dynamic Geometry Software, respectively for self-education on the geometric concept regular tessellations. In total 76 freshman students of the bachelor studies at the Purkyně University in Ustí nad Labem, Czech Republic were tested. We wanted to know, if they were able to explain why some regular polygons tessellate. It was the first time when the students met the concept regular tessellations. On the other hand all students had in the past the opportunity to work with the software GeoGebra. 
Students were acquainted with the concept regular tessellation only by the definition saying that if a (regular) figure can be used repeatedly to cover a surface without gaps or overlaps, is said to tessellate the surface and the resulting pattern is called a (regular) tessellation.

Then the questions as follows were given to students:

- Which regular polygons in the presented figure (see below the Image 1) will tessellate and which will not tessellate?

- What conditions have the angles of regular polygons satisfy in order for the polygons to tessellate?

Students were randomly divided into three groups. Students in the first group were provided with the figures of regular polygons drawn in the standard textbook. Students in the second group were provided with the Material Cards (just figures of regular polygons - they could manipulate with them immediately). Students in the third group were provided with the tablets and Geogebra Dynamic Geometry Software. Once a student found the solution of both questions, her time in minutes was measured; the maximum given time was 45 minutes - all students found the solutions sooner, however (and all solutions were correct).

Time (in minutes) needed for students to solve the problem was measured, see below the Table 1. The left upper corner number 15 in the column "Textbook" means time in minutes for the first student among them who were trying to solve the problem on the basis of the figures in the textbook. The second and the third columns give time for students solving the problems by means of Material Cards and GeoGebra, respectively.

We wanted to find out if there is any significant difference among these three methods for the proper understanding of the concept regular tessellations. So we used a single factor ANOVA in Excel to test the null hypothesis that the time means of these three populations (students provided with Textbook's figures, students provided with Material Cards and students provided with GeoGebra program) are all equal.

$\mathrm{H}_{0}: \mu_{1}=\mu_{2}=\mu_{3}$

$\mathrm{H}_{1}$ : At least one of the means is different.

Regular polygons from the first question look like this:
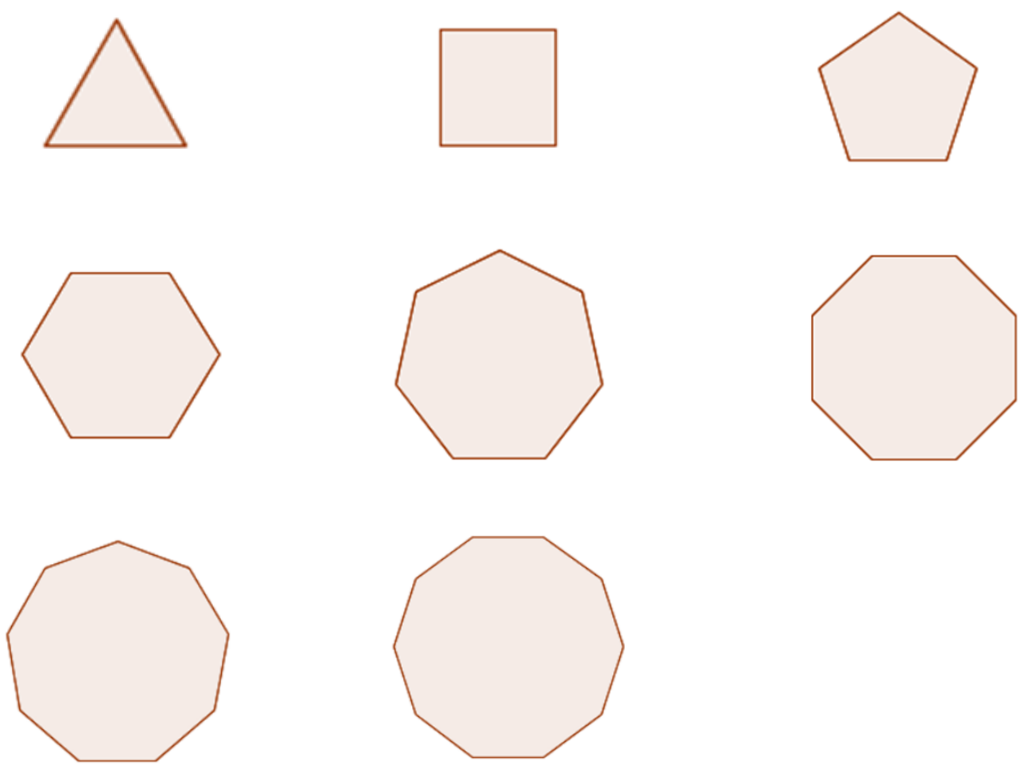

Image 1 - Figures in the Textbook: Regular Polygons \& Material Cards: Polygons for Regular Tessellations 
Students from both the group 1 and the group 2 worked only with these polygons - group 1 students (Textbook group) used only figures drawn on the paper, students from the group 2 (Cards group) could manipulate with figures' models.

Students from the group 3 (GeoGebra group) could use all tools of this software; there is their procedure in the following Images 2 - 8 .

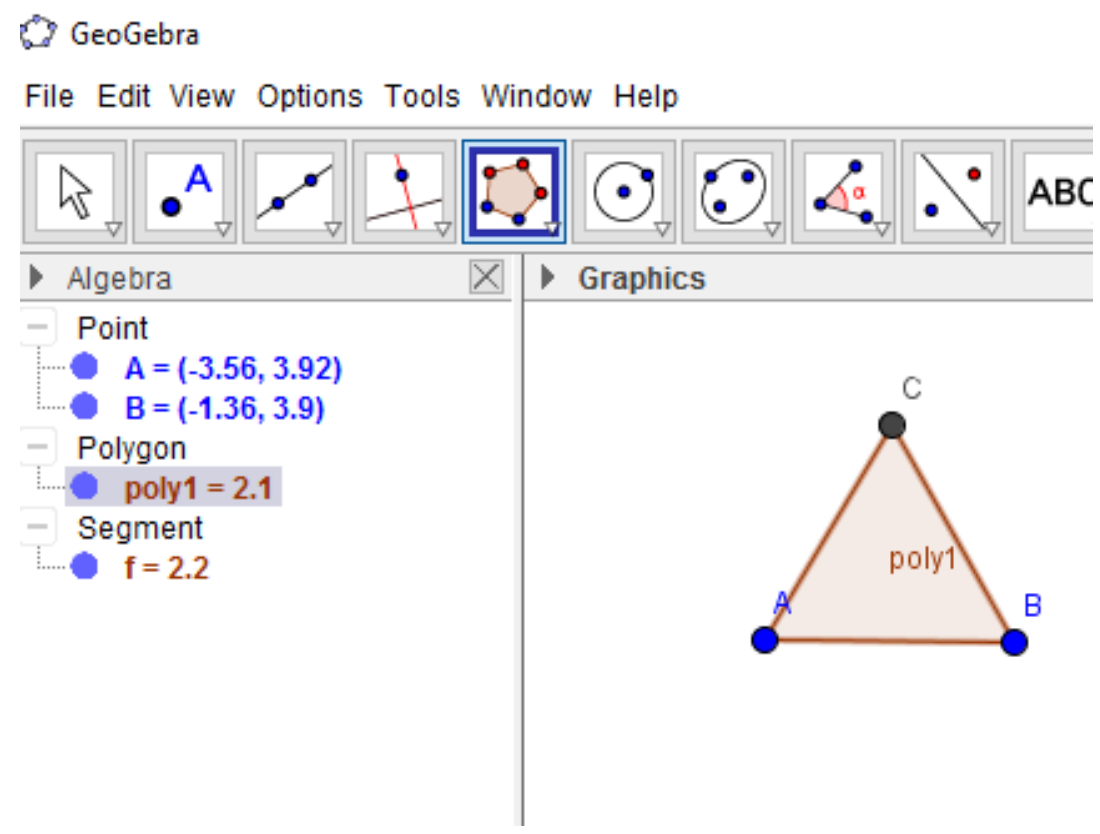

Image 2 - Equilateral triangle in the GeoGebra

GeoGebra

File Edit View Options Tools Window Help

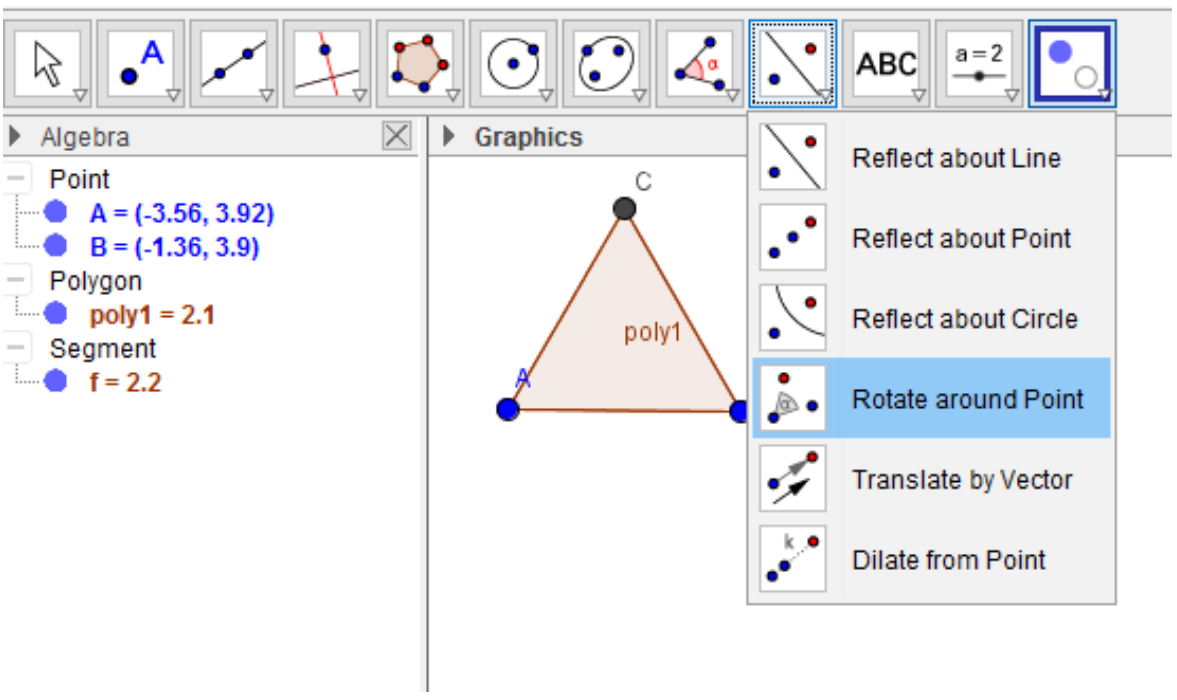

Image 3 - Equilateral triangle rotated around the point 
GeoGebra

File Edit View Options Tools Window Help

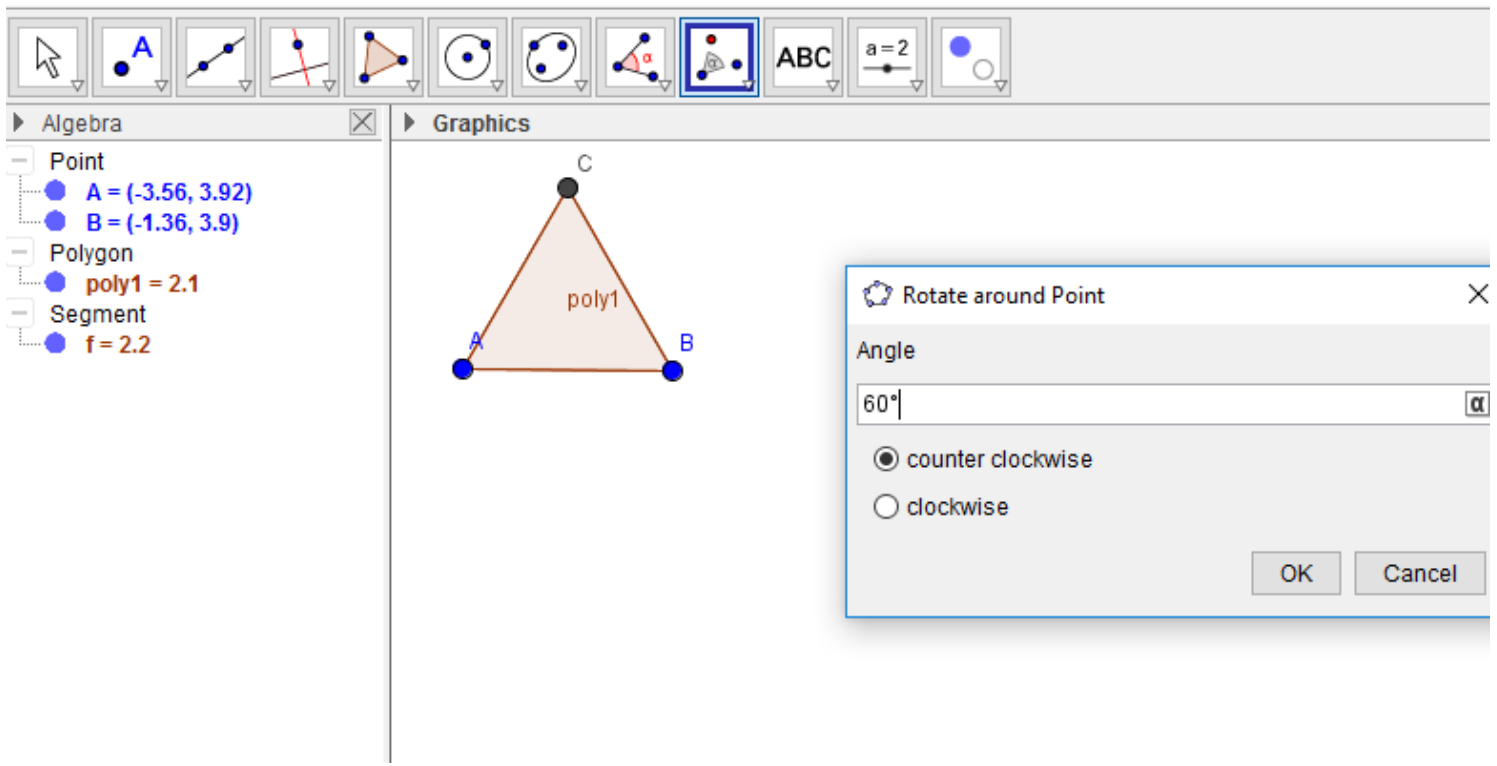

Image 4 - Equilateral triangle rotated around the point at $60^{\circ}$

GeoGebra

File Edit View Options Tools Window Help

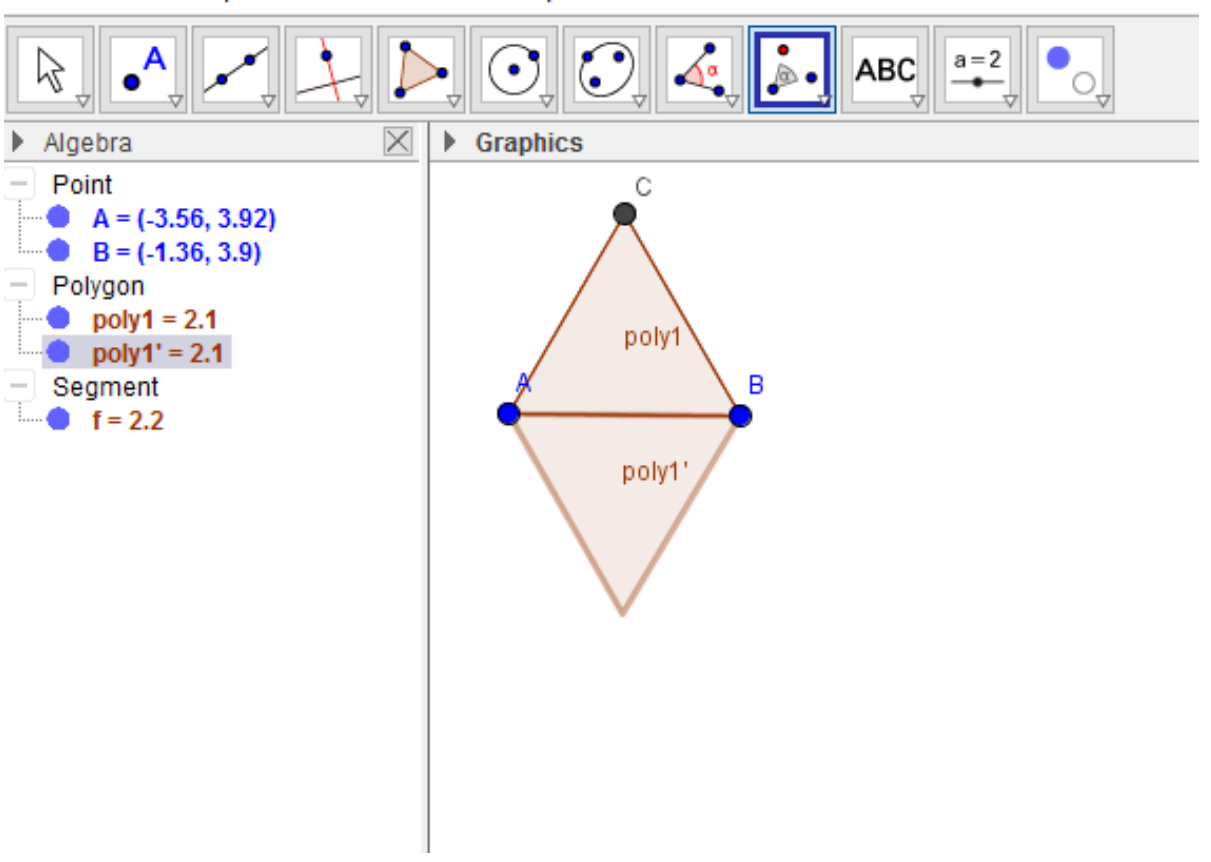

Image 5 - Tessellation starts 
If GeoGebra

File Edit View Options Tools Window Help

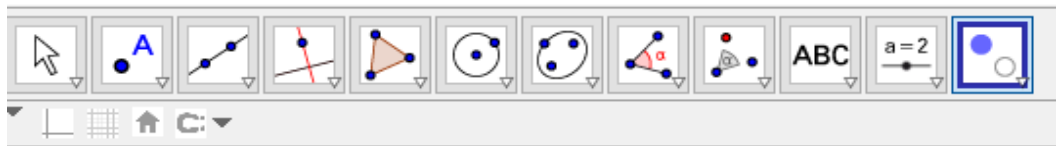

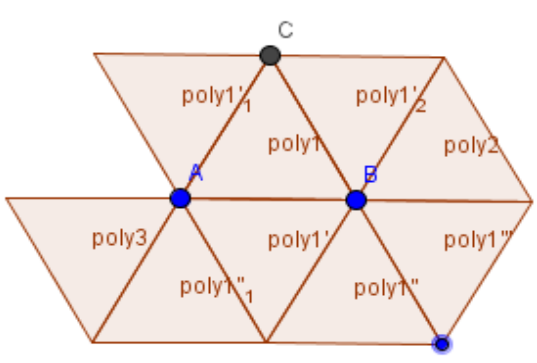

Image 6 - Tessellation continues

GeoGebra

File Edit View Options Tools Window Help

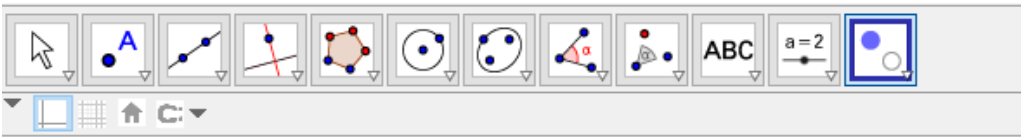
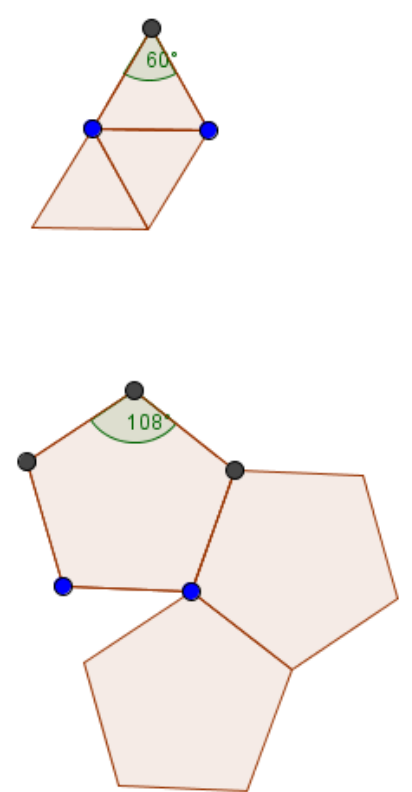
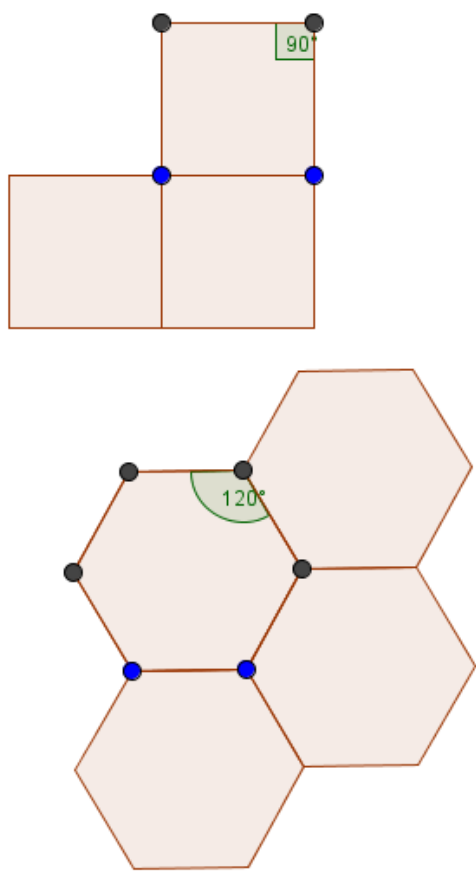

Image 7 - Trying to make Tessellations 1 
3 GeoGebra

File Edit View Options Tools Window Help

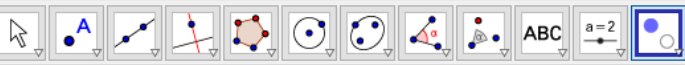

Ln Â C:
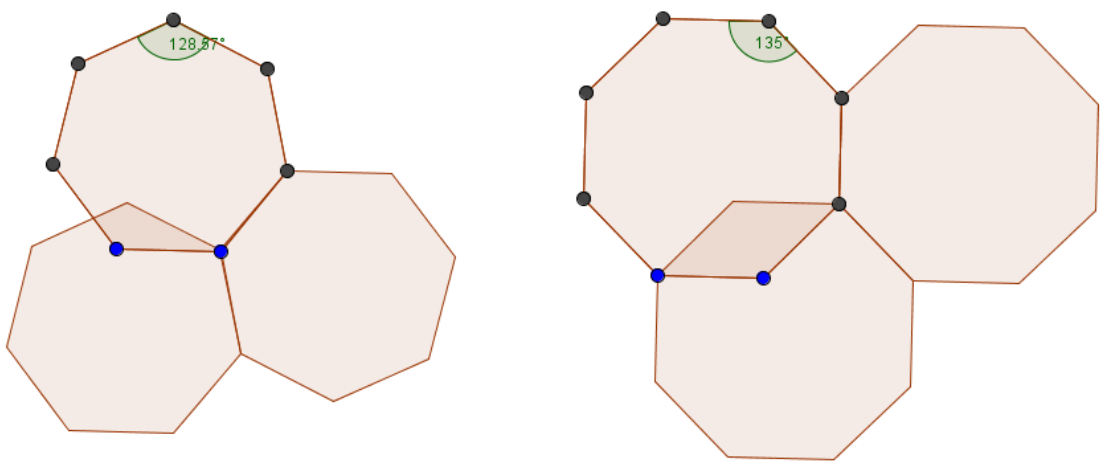

Image 8 - Trying to make Tessellations 2

Single Factor Anova method was used to test the null hypothesis that the time means of these three populations (Textbook, Cards and GeoGebra) are all equal.

Table 1: Anova: Single Factor from excel

\begin{tabular}{|c|c|c|c|c|c|c|c|c|c|c|}
\hline 4 & A & B & C & D & $\mathrm{E}$ & $\mathrm{F}$ & G & H & 1 & J \\
\hline 1 & Textbook & Cards & Geogebra & Anova: Single Facto & & & & & & \\
\hline 2 & 15 & 16 & 9 & & & & & & & \\
\hline 3 & 12 & 15 & 12 & SUMMARY & & & & & & \\
\hline 4 & 18 & 12 & 10 & Groups & Count & Sum & Average & $\overline{\text { Variance }}$ & & \\
\hline 5 & 15 & 10 & 11 & Column 1 & 27 & 394 & 14,59259 & 34,40456 & & \\
\hline 6 & 10 & 19 & 12 & Column 2 & 25 & 321 & 12,84 & 9,39 & & \\
\hline 7 & 12 & 10 & 10 & Column 3 & 24 & 312 & 13 & 12,17391 & & \\
\hline 8 & 19 & 16 & 14 & & & & & & & \\
\hline 9 & 31 & 11 & 13 & & & & & & & \\
\hline 10 & 32 & 12 & 19 & ANOVA & & & & & & \\
\hline 11 & 12 & 10 & 18 & Source of Variation & SS & $d f$ & $M S$ & $F$ & P-value & Fcrit \\
\hline 12 & 10 & 14 & 15 & Between Groups & 49,10832359 & 2 & 24,55416 & 1,280435 & 0,284083 & 3,122103 \\
\hline 13 & 19 & 13 & 10 & Within Groups & 1399,878519 & 73 & 19,17642 & & & \\
\hline 14 & 10 & 10 & 12 & & & & & & & \\
\hline 15 & 16 & 12 & 19 & Total & 1448,986842 & 75 & & & & \\
\hline 16 & 11 & 19 & 10 & & & & & & & \\
\hline 17 & 12 & 16 & 19 & & & & & & & \\
\hline 18 & 10 & 11 & 10 & & & & & & & \\
\hline 19 & 10 & 12 & 16 & & & & & & & \\
\hline 20 & 12 & 10 & 12 & & & & & & & \\
\hline 21 & 19 & 19 & 10 & & & & & & & \\
\hline 22 & 10 & 10 & 19 & & & & & & & \\
\hline 23 & 12 & 12 & 10 & & & & & & & \\
\hline 24 & 19 & 10 & 12 & & & & & & & \\
\hline 25 & 10 & 10 & 10 & & & & & & & \\
\hline 26 & 10 & 12 & & & & & & & & \\
\hline 27 & 16 & & & & & & & & & \\
\hline 28 & 12 & & & & & & & & & \\
\hline
\end{tabular}

As we can see from the above Table $1, F<F$ crit, it means we cannot reject the null hypothesis that all means are equal. 


\section{Conclusion}

The result of the presented research project did not show that, as for the self-education of the concept regular tessellations, the efficiency of the Dynamic Geometry Software was very high - we cannot say that there were significant differences among used methods (traditional versus new one, supported by ICT).

\section{Acknowledgement}

This paper was supported by specific research project "ICT in Mathematics at elementary schools in Olomouc and Leshan City", Project No. IGA_PdF_2016_009, realized at the Department of Mathematics, Faculty of Education, Palacký University in Olomouc.

\section{Bibliography}

1. CLEMENTS D. H., BATTISTA M. T. Geometry and spatial reasoning. In D. A. Grouws (ed.), Handbook of research on Mathematics Teaching and Learning. New York: Macmillan, 1992.

2. GOMES, A. S., QUEIROZ, A. E. M., CARVALHO, F. A. T., ALVES, F. J. A. The Learning of geometric concepts using Dynamic Geometry Software. In: Julie A. Jacko (ed.) \& Constantine Stephanidis (ed.), HCI INTERNATIONAL 2003, Creta, Grécia. Human Computer Interaction, International Proceedings 2003. Lawrence Erlbaum Associates, Inc., 2003.

3. NOCAR, D. - NOVÁK, B. Objevujeme s Cabri. In Studia Scientifica Facultatis Paedagogicae Universitatis Catholica Ružomberok, Rok 2015, ročník 14, čislo 2. Ružomberok: Verbum vydavatel'stvo Katolickej univerzity, 2015. ISSN 1336-2232.

4. NOCAR, D. - ZDRÁHAL, T. The Potential of Dynamic Geometry for Inquiry Based Education. In EDULEARN15 Proceedings. Barcelona: IATED, 2015. ISBN 978-84-606-82431 / ISSN 2340-1117.

\section{Address:}

David Nocar, Mgr., Ph.D.

Department of Mathematics, Faculty of Education at Palacký University in Olomouc, Žižkovo nám. 5, 77140 Olomouc, CZ, tel.: +420 585635 709, e-mail: david.nocar@upol.cz

Tomáš Zdráhal, doc. RNDr., CSc.

Department of Mathematics, Faculty of Education at Palacký University in Olomouc, Žižkovo nám. 5, 77140 Olomouc, CZ, tel.: +420 585635 710, e-mail: tomas.zdrahal@upol.cz 